\title{
Price clusters and stock price stability
}

\section{Clusters de preços e estabilidade do preço das ações}

\author{
Hamid Reza Kordlouie' \\ Mehrnoush Ebrahimi" \\ Narges Mohseni Dehkolani"I \\ Azam Zare Jafar Kolaei ${ }^{\text {IV }}$
}

\begin{abstract}
Understanding the factors affecting stock return volatility, for analysts, investors and company executives, it is critical. In this study, using a traditional approach, we identify the factors influencing volatility and how price friction is formed on stock price stability, and in particular, examining the clustering test for price increases. This study was carried out by examining the price clusters and stock price stability in the stock market and the OTC market between 2009 -2010. Econometric software was used to investigate the research variables. In this study, we tried to study stock price volatility in proportion to stock price clusters. Research findings showed; there is no significant relationship between stock price volatility and price clusters in the OTC market and the stock market.
\end{abstract}

Keywords: Price Clusters; Stock Price Fluctuations; Stock Returns Fluctuations; Stock Market; OTC Market

\section{Resumo}

Compreender os fatores que afetam a volatilidade do retorno das ações, para analistas, investidores e executivos da empresa, é fundamental. Neste estudo, usando uma abordagem tradicional, identificamos os fatores que influenciam a volatilidade e como o atrito dos preços é formado na estabilidade dos preços das ações e, em particular, examinamos o teste de agrupamento para aumento de preços. Este estudo foi realizado examinando os clusters de preços e a estabilidade dos preços das ações no mercado de ações e no mercado de balcão entre 2009 e 2010. O software econométrico foi utilizado para investigar as variáveis da pesquisa. Neste estudo, tentamos estudar a volatilidade do preço das ações na proporção dos clusters de preços das

\footnotetext{
I Associate Professor, Department of Accounting, Islamshahr Branch, Islamic Azad University, Tehran, Iran Hamidreza.kordlouie@gmail.com

"PhD student, Department of Accounting, Qeshm International Branch, Islamic Azad University, Qeshm, Iran ghazalmehr2005@gmail.com

IIIPhD student, Department of Accounting, Qeshm International Branch, Islamic Azad University, Qeshm, Iran dehkalani_n@yahoo.com

IVMaster of Financial and Accounting Management, Qaemshahr Branch, Islamic Azad University, Qaemshahr, Iran - Azam.azre91@gmail.com
} 
ações. Os resultados da pesquisa mostraram; não há relação significativa entre a volatilidade do preço das ações e os clusters de preços no mercado de balcão e no mercado de ações.

Palavras-chave: Clusters de preços; Flutuações dos preços das ações; Flutuações dos retornos das ações; Mercado de ações; Mercado de balcão 


\section{Introduction}

For the past three decades, modeling and predicting asset volatility has been one of the major issues in the financial field. When referring to the stock return process, volatility, the standard deviation of the process, is often defined this measures the random component distribution of returns. This is why most people interpret volatility as uncertainty. Large volatility values make the stock return component unpredictable, as well as its smaller values; it can estimate the expected return. As it grows, it makes it very difficult to predict future returns on assets from historical returns (EDRAKIL AND TEHRANI, 2012). Stock prices change depending on how much supply and demand change. Given the highly non-linear nature of stock price movements, predicting stock prices and timing a buy-and-sell decision is a very challenging task. There is a risk that there will be a tendency for collective movement in the stock market. Preliminary studies have examined stock market forecasts (KLOSE, 1933), studies have claimed to be random movements in stock prices (Cotter, 196), (FAMA, 1965). The labor market hypothesis has ruled out the possibility of any additional return on the market. However, recent studies, for example (ATSALIX \& WALLONIS, 2009), (NAIR \& MONDAS, 2015), NAIR \& MOHAN, 2015) have shown that; it is possible to predict stock price movements and predict additional returns. Given the complex nature of the market and recent financial crises, a better understanding of stock price movements is essential, in this regard, different statistical methods have been used to analyze financial data and explore the relationship between these variables with stock prices. For example, returns do not show a serial correlation asset, however, the long-term memory of the stock returns with a longer break is longer and based on the series of financial returns, the Gaussian distribution method and the absolute value of the equity series; it tends to follow a particular law. It has also shown that; there are nonlinear phenomena such as cluster oscillations and switching behaviors (GIANG \& CHI, 2012; ZHANG \& WANG, 2015). Other studies have shown that when multiple assets are considered together, most returns series are correlated, and this relationship becomes even larger in times of financial crisis. Correlation and time series analysis play an important role in predictions (CYAN et al., 2016). 
Many economic theories have focused on the formation of equilibrium prices. However, in practice, due to friction, it will have a detrimental effect on the equilibrium price. For example, empirical research has shown that; Prices tend to move around the value and market value categories. Explaining this kind of abnormal price behavior is usually categorized by two views. First, investors prefer a certain number of prices, which is to reduce cognitive processing costs. Second, the first reason is not a unique explanation, and it is believed that investors prefer trading at certain prices, which is to reduce negotiation costs. Whereas previous research on financial markets has made categories in financial markets but few studies have examined the impact of classification on the quality of financial markets. The purpose of this study is to test the clustering degree hypothesis on the values of stock price increases that lead to lower stock stability. The theory of this hypothesis focuses on the information transmission system to market participants. When prices are around price increases, they may decline due to a lack of pricing information on stocks. Therefore, higher clustered stocks may have higher volatility levels. Survey results show that: investor preferences over price limits - whether due to behavioral bias or avoidance of negotiation costs - due to lack of information, can affect stock prices and increase stock price volatility. This research has been conducted in light of the literature on stock price volatility and its volatility. Managers are trying to maximize shareholder wealth by taking into account the level of stock price volatility; these fluctuations can affect the cost of corporate capital. Early studies have shown excessive volatility in financial markets, in this study, we examine the level of price friction and the fluctuations of the clusters around the stock closing prices. This research is conducted in the period of 2010-2016.

\section{Literature Review}

Risk assessment and return are important components in investment decisions. These are basically two sides of a coin that one cannot evaluate without the other. The positive relationship between risk and return indicates the risk aversion of investors. The stock market naturally reflects business cycles and economic conditions. Based on economic and financial theories, stock prices are determined by the present value of its expected cash flows. Thus 
any factor that affects the present value of expected cash flows of stocks will clearly affect the stock price (LEVINTS \& GAVANTEX, 2015). According to economic theories, the stock price index should reflect the expectations of individuals for the future performance of companies, while corporate profits reflect the level of economic activity. If the stock price index accurately reflects information on the future trend of the underlying variables, then it can be used as a leading variable to predict volatility in economic activity. Therefore, the scientific relationships and dynamic interactions between macroeconomic variables and the stock price index are crucial in formulating a country's macroeconomic policies. Many studies have addressed the relationship between stock price indices and macroeconomic variables (For example, CHANG AND TAI, 1998; KARA MUSTAFA \& KOKOKALE (2004) AND MILLER \& SCHOFENG (2001). The stock market is crucial for determining economic progress. It is essential to focus on the factors that generate equity returns. While financial theories focus on specific companies and industries, there is a growing belief among financial researchers that macroeconomic variables play a critical role in determining the market performance of stocks (TRUFFY \& KUMAR, 2014). Predicting the volatility of stock markets and the degree of stability of these markets is one of the most important issues studied in the financial markets of the world. Fluctuations as an effective factor in determining investment risk can play an important role in investor decision making and it is crucial in determining the return on corporate equity in different financial markets. One important thing is that the nature of the volatility varies across markets. Also, while the use of statistical and econometric methods in the study of volatility in most developed countries' financial markets has received much attention, but there has been no universal way of examining high reliability stock returns. That is, if one market is more efficient in one market, it will not perform in another. The issue of stock market turbulence over the last few decades has been one of the most important issues in the financial literature. The main function of financial markets in the economy is to provide a method of directing and allocating capital from the holders of surplus funds to investors in need of financial resources. During this process, the price of financial assets is caused by volatility in economic activity, a form of price volatility, which is considered as a common occurrence in market performance. However, by finding volatile patterns for different stocks on the market and using stock price forecasting, a more efficient 
process of capital allocation can be made. Cluster turbulence patterns are among the turbulent patterns of stock returns. Modeling returns volatility in stock markets, from the perspective of academic researchers and financial science practitioners, is important in terms of its use in predicting stock returns. Studies have shown that; information about financial variables flows through the assets market over time. This has become more important as financial markets become more interconnected and increasingly interconnected. The mechanisms of contagion between returns and volatility of different assets are important for a number of reasons. First, contamination mechanisms give us information about market efficiency. The spread between return on assets indicates a lucrative trading strategy and if the profitability of this trading strategy is higher than its operating costs, it potentially provides evidence of market inefficiency. Second, the contagion mechanisms are important in asset management, because having information on the impact of returns spread on portfolio selection and risk reduction is very useful. Third, information on the spread of asset turbulence can be used to predict turbulence; therefore, asset turbulence spreads are applied to such topics as option pricing, portfolio optimization, and risk exposure and risk management. The returns of large and small shares are correlated to different stock exchanges. In addition, numerous studies, some of which are described below, have shown that: This is asymmetric intersection solidarity, that is, the returns of small-cap stocks are correlated with the lagged returns of large-cap stocks, and however, the returns of the portfolio of large corporations do not have a significant correlation with the delayed returns of the portfolio of small companies. This asymmetric delay correlation between large and small shares, which is a particular mode of asset circulation, is called the priority-delay effect. In other words, the hypothesis states that the delays in the portfolio of small coats are delayed by the returns of the portfolio of large corporations, but the opposite is not true. One of the first studies to investigate the stochastic step hypothesis using size-order stock portfolios is the study of LU and MCCONNELL (1998). He strongly rejects the existence of a random step using the weekly data of five portfolio-sized stocks from Neice and Aimex and showed that although individual returns have weak and usually negative autocorrelation, there is a strong positive correlation between returns. Lu and McConnell attributed these results to the existence of a cross-correlation between returns on individual shares. In 
another study, LU AND MCCONNELL (1990) found another notable difference between the behavior of a small share portfolio and a large share portfolio and showed that the yields of small stock portfolios are more predictable than those of large stocks. They also showed that the delayed returns of the portfolio of large firms can explain a significant portion of the current returns of the small portfolio; but the opposite is not the case. Therefore, they observed an asymmetry in the predictability of returns of large and small firms' stock portfolios. Other researchers then tested the existence of a late-priming effect in different markets and for different periods.

HARRIS (1991) has shown that there is a positive relationship between the number of clusters and the yield fluctuations. However, these results are not the same for annual observations. Recent studies have also shown a positive relationship between volatility and stock price clustering, in general, it supports the hypothesis of BALL et al (1985) that clustering depends on known values. CHANG AND ZHANG (2014) and ROLL \& SABRIAM (2010) suggested that; the range of daily quotations explains well the extent of trading. ALEXANDER AND PATTERSON (2008) examined the effect of price clusters on trading volume. They found that the average size of transactions around the highest prices was traded. CONBURY AND WATSON (2008) found that price movements between the New York Stock Exchange and NASDAQ were similar, given the firm's other firm characteristics. In contrast, GROSSMAN (1997) stated that; Market structure plays a decisive role in explaining stock cluster prices. CHRISTIE AND SCHULTZ (1994) showed that; Spread and clustering are positively correlated as sellers operate in their trades based on their preferences across different industry groups. HUANG AND STONE (1996) also showed a relationship between clusters and price range, they stated that the relationship between these two variables is influenced by economic factors. ADRIJACKING WEJANG (2008) examined portfolio selection based on financial strength index using data envelopment analysis. They used a series of financial ratios to estimate firms' financial strength and their correlation with actual stock returns. The financial ratios used in this study are divided into 6 categories, including: Profitability metrics (including return on capital, return on assets, net profit margin, earnings per share), Operational efficiency criteria (including accounts receivable turnover, inventory turnover, asset turnover), Liquidity criteria (including current ratio, instant ratio and debt to 
equity ratio), Leverage criteria (including leverage ratio, total debt-to-asset ratio, total debtto-equity ratio), Company Outlook Criteria (Including Price to Income Ratio and Market Value to Office Ratio) And growth metrics (including earnings growth rate, net profit growth rate and earnings growth rate per share). In this study, using cluster analysis based on the industry standard global index, we have shown that traditional approaches used in hybrid clusters provide a good link for portfolio diversification.

BENJAMIN and JEFFERIES (2016) examined stock clustering and stock price stability. In this study, using a non-traditional approach, we identified stock price volatility based on a series of frictions affecting stock price stability. The results showed that there is a strong and positive relationship between stock price clusters and stock price volatility.

\section{Model and Data}

During this study, we study the frequency of clusters, yield fluctuations and price fluctuations. To estimate the frequency of clusters (cluster \%), the closing price is determined around the price in the given period. Clusters are defined according to defined industry codes. Two criteria are used to measure stock price stability. The first variable is the Rvolt, which is considered as the standard deviation of daily stock returns. The second variable also uses low frequencies of price volatility (Pvolt) and derives the difference between the high and low prices of the monthly index.

Several other criteria are used as control variables for multivariate analysis. Mktcap is considered the size of the company and it is obtained by multiplying the closing price by the number of shares issued. Company size is negatively correlated with the abundance of price clusters. The price is also the average share price over a month. The nominal price per share is likely to be positively correlated with price clusters. The spreading of the stock price is also another variable to consider which is obtained by averaging the daily purchase price over a month. Liquidity variable (illiq) is also measured by Liquidity AMIHOOD (2002) and it is obtained by dividing the absolute value of the return by the volume of the transaction. Turnover is also derived from the proportion of monthly transactions relative to large stock market transactions. Trading volume with stock clusters is expected to be inversely related. 
According to the variables mentioned, the relationship between the variables in two markets is investigated using multi-variable regression model and we compare the relationships between the two markets.

volatility $_{\text {torism }_{t}}$

$$
\begin{aligned}
& =\beta_{0}+\beta_{1} \text { cluster }_{i, t}+\beta_{2} \text { Market index }_{t}+\beta_{3} \ln \left(\text { mktcap }_{i, t}\right)+\beta_{4} \ln \left(\text { price }_{i, t}\right) \\
& +\beta_{5} \text { turn }_{i, t}+\beta_{6} \text { speard }_{i, t}+\beta_{7} \text { illiq }_{i, t}+\varepsilon_{t}
\end{aligned}
$$

In this paper, we attempted to eliminate the deficiencies in previous studies by applying the latest estimation methods in panel data and to present consistent and reliable results. In this study, the price information and returns of companies are determined based on the industrial clusters given in Table (1) and the research model is tested.

\begin{tabular}{|c|c|c|c|}
\hline $\begin{array}{r}\text { Industry } \\
\text { codes ISIC }\end{array}$ & $\begin{array}{l}\text { Industry } \\
\text { name }\end{array}$ & $\begin{array}{r}\text { Industry } \\
\text { codes ISIC }\end{array}$ & $\begin{array}{l}\text { Industry } \\
\text { name }\end{array}$ \\
\hline 17 & textiles & 27 & basic metals \\
\hline 19 & $\begin{array}{l}\text { Tanning, } \\
\text { leather and } \\
\text { footwear }\end{array}$ & 28 & $\begin{array}{r}\text { Metal } \\
\text { products }\end{array}$ \\
\hline 20 & $\begin{array}{l}\text { Wooden } \\
\text { products }\end{array}$ & 29 & $\begin{array}{c}\text { equipment } \\
\text { and machinery }\end{array}$ \\
\hline 21 & $\begin{array}{r}\text { Paper } \\
\text { products }\end{array}$ & 30 & $\begin{array}{r}\text { Electric } \\
\text { appliances }\end{array}$ \\
\hline 23 & $\begin{array}{c}\text { Oil, } \\
\text { nuclear }\end{array}$ & 33 & $\begin{array}{l}\text { Measurement, } \\
\text { medicine }\end{array}$ \\
\hline 24 & Chemical & 34 & $\begin{array}{l}\text { Vehicle and } \\
\text { auto parts }\end{array}$ \\
\hline 25 & $\begin{array}{l}\text { Rubber } \\
\text { \& Plastic }\end{array}$ & & \\
\hline
\end{tabular}

Table 1 - Industry codes

To test the research variables, two markets are examined. The return on research at the stock exchange was between 2010-2016. 103 companies were systematically eliminated from the stock exchange. A total of 31 companies were selected as examples from the crossover. 


\section{Result}

\subsection{Descriptive Statistics}

The first step in statistical analysis is to determine the summarized characteristics of the data and calculate the descriptive indices. The purpose of this analysis is to identify the internal relationships of variables and to show the behavior of the subjects in order to provide the bases for statistical analysis and to provide descriptive characteristics for further analysis (Hooman 1991). Data analysis in this section was performed by calculating central indices such as mean and median and dispersion indices such as standard deviation, maximum and minimum values of variables.

Table 2- Descriptive statistics of the research variables of stock companies

\begin{tabular}{|c|c|c|c|c|c|c|c|c|c|}
\hline & $\begin{array}{l}\text { CLU } \\
\text { STER }\end{array}$ & $\begin{array}{l}\text { ILLI } \\
\mathbf{Q}\end{array}$ & $\begin{array}{r}\text { LNM } \\
\text { KTCAP }\end{array}$ & $\begin{array}{l}\text { LNP } \\
\text { RICE }\end{array}$ & $\begin{array}{r}\text { MA } \\
\text { RKET }\end{array}$ & $\begin{array}{l}\text { PV } \\
\text { OLT }\end{array}$ & $\begin{array}{l}\text { RV } \\
\text { OLT }\end{array}$ & $\begin{array}{l}\text { SPE } \\
\text { ARD }\end{array}$ & $\begin{array}{l}\text { TUR } \\
\mathrm{N}\end{array}$ \\
\hline $\begin{array}{l}\text { Aver } \\
\text { age }\end{array}$ & $\begin{array}{r}632 \\
4.892\end{array}$ & $\begin{array}{r}294 \\
462.1\end{array}$ & $\begin{array}{l}25.58 \\
841\end{array}$ & $\begin{array}{r}8.59 \\
3471\end{array}$ & $\begin{array}{r}615 \\
8.133\end{array}$ & $\begin{array}{c}121 . \\
9927\end{array}$ & $\begin{array}{r}234 . \\
6785\end{array}$ & $\begin{array}{c}69.1 \\
581\end{array}$ & $\begin{aligned} & 3.2 \mathrm{E} \\
+ & 08\end{aligned}$ \\
\hline $\begin{array}{l}\text { Midd } \\
\text { le }\end{array}$ & $\begin{array}{r}335 \\
0.55 \\
\end{array}$ & $\begin{array}{r}235 \\
09.94 \\
\end{array}$ & $\begin{array}{l}25.52 \\
837\end{array}$ & $\begin{array}{l}8.43 \\
221\end{array}$ & $\begin{array}{r}324 \\
8.132\end{array}$ & $\begin{array}{r}66.1 \\
4319 \\
\end{array}$ & $\begin{array}{r}131 . \\
9535\end{array}$ & $\begin{array}{r}38.0 \\
4795\end{array}$ & $\begin{array}{r}314 \\
31627\end{array}$ \\
\hline $\begin{array}{l}\text { maxi } \\
\text { mum }\end{array}$ & $\begin{array}{l}540 \\
78\end{array}$ & $\begin{array}{r}354 \\
14119\end{array}$ & $\begin{array}{l}29.77 \\
535\end{array}$ & $\begin{array}{r}11.0 \\
0829\end{array}$ & $\begin{array}{r}605 \\
70.04\end{array}$ & $\begin{array}{r}115 \\
8.34\end{array}$ & $\begin{array}{r}500 \\
4.15\end{array}$ & $\begin{array}{r}579 . \\
1698\end{array}$ & $\begin{array}{r}1.01 \\
E+10\end{array}$ \\
\hline $\begin{array}{l}\text { mini } \\
\text { mum }\end{array}$ & 387 & $\begin{array}{r}420 . \\
0518\end{array}$ & $\begin{array}{l}20.83 \\
247\end{array}$ & $\begin{array}{r}6.12 \\
3874\end{array}$ & $\begin{array}{r}457 . \\
4348\end{array}$ & $\begin{array}{r}0.02 \\
5641\end{array}$ & $\begin{array}{l}16.7 \\
8\end{array}$ & 0.01 & $\begin{array}{l}629 \\
6\end{array}$ \\
\hline \begin{tabular}{l}
\multicolumn{1}{c}{ Stan } \\
dard \\
deviatio \\
$\mathrm{n}$
\end{tabular} & $\begin{array}{r}768 \\
6.386\end{array}$ & $\begin{array}{r}208 \\
7138\end{array}$ & $\begin{array}{l}1.600 \\
561\end{array}$ & $\begin{array}{r}1.01 \\
6293\end{array}$ & $\begin{array}{r}725 \\
5.984\end{array}$ & $\begin{array}{r}166 . \\
8533\end{array}$ & $\begin{array}{r}404 . \\
6806\end{array}$ & $\begin{array}{r}86.3 \\
5593\end{array}$ & $\begin{array}{r}1.07 \\
E+09\end{array}$ \\
\hline $\begin{array}{l}\text { Skew } \\
\text { ness }\end{array}$ & $\begin{array}{r}2.90 \\
2513\end{array}$ & $\begin{array}{c}14.2 \\
0767\end{array}$ & $\begin{array}{l}0.658 \\
656 \\
\end{array}$ & $\begin{array}{c}0.34 \\
3733\end{array}$ & $\begin{array}{l}3.07 \\
685\end{array}$ & $\begin{array}{r}3.22 \\
0523\end{array}$ & $\begin{array}{r}7.59 \\
6093\end{array}$ & $\begin{array}{r}2.87 \\
5184\end{array}$ & $\begin{array}{r}6.07 \\
2996\end{array}$ \\
\hline $\begin{array}{l}\text { Elong } \\
\text { ation }\end{array}$ & $\begin{array}{r}12.8 \\
8346\end{array}$ & $\begin{array}{r}217 . \\
7338\end{array}$ & $\begin{array}{l}3.574 \\
888\end{array}$ & $\begin{array}{r}2.54 \\
4987\end{array}$ & $\begin{array}{r}16.2 \\
1832\end{array}$ & $\begin{array}{c}15.2 \\
2606\end{array}$ & $\begin{array}{r}76.1 \\
6677\end{array}$ & $\begin{array}{l}12.9 \\
252\end{array}$ & $\begin{array}{r}42.5 \\
6867\end{array}$ \\
\hline
\end{tabular}




\begin{tabular}{c|r|r|r|r|r|r|r|r|r}
\hline $\begin{array}{c}\text { Jark- } \\
\text { bra }\end{array}$ & $\begin{array}{r}314 \\
9.801\end{array}$ & $\begin{array}{r}114 \\
9030\end{array}$ & $\begin{array}{c}46.98 \\
366\end{array}$ & $\begin{array}{r}20.5 \\
6691\end{array}$ & $\begin{array}{r}511 \\
6.869\end{array}$ & $\begin{array}{r}459 \\
3.761\end{array}$ & $\begin{array}{r}136 \\
407.6\end{array}$ & $\begin{array}{r}315 \\
4.279\end{array}$ & $\begin{array}{r}417 \\
23.75\end{array}$ \\
\hline $\begin{array}{c}\text { mean } \\
\text { ingful }\end{array}$ & 0 & 0 & 0 & 0 & 0 & 0 & 0 & 0 & 0 \\
\hline $\begin{array}{c}\text { Com } \\
\text { pany } \\
\text { Number }\end{array}$ & 103 & 103 & 103 & 103 & 103 & 103 & 103 & 103 & 103 \\
\hline $\begin{array}{c}\text { View } \\
\text { count }\end{array}$ & 721 & 0 & 0 & 0 & 0 & 0 & 0 & 0 & 0 \\
\hline
\end{tabular}

Table 3- Descriptive statistics of research variables in the initial state of the stock exchange companies

\begin{tabular}{|c|c|c|c|c|c|c|c|c|c|}
\hline & $\begin{array}{l}\text { CLU } \\
\text { STER }\end{array}$ & $\begin{array}{l}\text { ILLI } \\
\mathbf{Q}\end{array}$ & $\begin{array}{r}\text { LNM } \\
\text { KTCAP }\end{array}$ & $\begin{array}{l}\text { LNP } \\
\text { RICE }\end{array}$ & $\begin{array}{r}\text { MA } \\
\text { RKET }\end{array}$ & $\begin{array}{c}\text { PV } \\
\text { OLT }\end{array}$ & $\begin{array}{c}\text { RV } \\
\text { OLT }\end{array}$ & $\begin{array}{l}\text { SPE } \\
\text { ARD }\end{array}$ & $\begin{array}{l}\text { CLU } \\
\text { STER }\end{array}$ \\
\hline Avera & 262 & 900 & 4.83 & 7.05 & & 76.0 & 53.6 & 3.4 & 262 \\
\hline ge & 0.473 & 644.9 & 772 & 3786 & 55.48 & 1046 & 4694 & 9117 & 0.473 \\
\hline Midd & 182 & 981 & 24.87 & 6.98 & 226 & 49.8 & 35.2 & 5.05 & 182 \\
\hline le & 1.342 & 8.755 & 383 & 813 & 78.23 & 1006 & 2103 & 7712 & 1.342 \\
\hline maxi & & 690 & & 9.83 & 802 & 679. & 480. & 286. & \\
\hline mum & 68.11 & 12658 & 772 & 3326 & 19 & 4 & 4083 & 4375 & 68.11 \\
\hline $\operatorname{mini}$ & 25.8 & 538. & & 6.33 & 797 & & & 0.03 & 25.8 \\
\hline mum & 5075 & 1617 & 717 & 5276 & 2 & & & 0568 & 5075 \\
\hline $\begin{array}{l}\text { Stan } \\
\text { dard }\end{array}$ & 264 & 665 & 1.354 & 0.65 & 251 & 96.7 & 68.4 & 27.9 & 264 \\
\hline $\begin{array}{l}\text { deviatio } \\
\mathrm{n}\end{array}$ & 6.136 & 1813 & 338 & 1842 & 92.76 & 6808 & 127 & 6544 & 6.136 \\
\hline Skew & 2.87 & 8.25 & - & 0.64 & 0.60 & 2.90 & 2.91 & 5.00 & 2.87 \\
\hline ness & 9793 & 6684 & 0.31983 & 6865 & 9403 & 564 & 1288 & 9948 & 9793 \\
\hline Elong & 13.4 & 76.6 & 2.125 & 3.16 & 1.67 & 13.7 & 13.7 & 38.1 & 13.4 \\
\hline ation & 9551 & 2709 & 256 & 0561 & 7015 & 1442 & 4167 & 095 & 9551 \\
\hline Jark- & 120 & 467 & 6.619 & 14.9 & 21.6 & 125 & 125 & 110 & 120 \\
\hline bra & 9.978 & 04.12 & 995 & 5259 & 7131 & 3.563 & 9.508 & 05.32 & 9.978 \\
\hline
\end{tabular}




\begin{tabular}{|c|c|c|c|c|c|c|c|c|c|}
\hline $\begin{array}{l}\text { mean } \\
\text { ingful }\end{array}$ & 0 & 0 & $\begin{array}{l}0.025 \\
192\end{array}$ & $\begin{array}{r}0.00 \\
0272\end{array}$ & 0 & 0 & 0 & 0 & 0 \\
\hline $\begin{array}{l}\text { Com } \\
\text { pany } \\
\text { Number }\end{array}$ & 30 & 30 & 30 & 30 & 30 & 30 & 30 & 30 & 30 \\
\hline $\begin{array}{l}\text { View } \\
\text { count }\end{array}$ & 210 & 210 & 210 & 210 & 210 & 210 & 210 & 210 & 210 \\
\hline
\end{tabular}

\subsection{The linearity of the variables}

Linear econometrics occurs when two or more of the two (independent) explanatory variables in a multivariate regression are highly correlated to each other. The correlation here implies a linear relationship between the independent variables. Depending on the severity of the correlations between the independent variables, the magnitude and type of the correlations will vary. Linearity is more or less present in all regression models; what is important is the intensity of the correlations between the independent variables. The existence of a "perfect line" violates the classical regression model assumptions. In this study, correlation coefficient between them was used to investigate the linearity between explanatory variables. The results are shown in Tables (4) and (5).

Table 4- Value of correlation coefficient in stock exchange companies

\begin{tabular}{l|c|c|c|c|c|c|c|c}
\hline $\begin{array}{l}\text { Correlat } \\
\text { ion }\end{array}$ & $\begin{array}{c}\text { CLUST } \\
\text { ER }\end{array}$ & $\begin{array}{c}\text { ILLI } \\
\text { Q }\end{array}$ & $\begin{array}{c}\text { MKTC } \\
\text { AP }\end{array}$ & $\begin{array}{c}\text { PRI } \\
\text { CE }\end{array}$ & $\begin{array}{c}\text { PVO } \\
\text { LT }\end{array}$ & $\begin{array}{c}\text { RVO } \\
\text { LT }\end{array}$ & $\begin{array}{c}\text { SPEA } \\
\text { RD }\end{array}$ & $\begin{array}{c}\text { TUR } \\
\text { NLUSTER }\end{array}$ \\
\hline ILLIQ & -0.202 & 1 & & & & & & \\
\hline MKTCAP & 0.14 & 0.2 & 1 & & & & & \\
\hline PRICE & 0.502 & - & -0.23 & 1 & & & & \\
\hline PVOLT & 0.066 & -0.1 & -0.376 & 0.40 & 1 & & & \\
\hline
\end{tabular}




\begin{tabular}{c|c|c|c|c|c|c|c|c}
\hline RVOLT & -0.202 & 0.5 & 0.266 & - & - & 1 & & \\
& & 32 & & 0.544 & 0.098 & & & \\
\hline SPEARD & 0.47 & - & -0.17 & 0.59 & 0.41 & - & 1 & \\
& & 0.27 & & 4 & 8 & 0.266 & & \\
\hline TURN & 0.074 & 0.4 & 0.098 & - & 0.16 & 0.47 & 0.412 & 1 \\
& & 7 & & 0.432 & 4 & & & \\
\hline
\end{tabular}

Table 5- Correlation coefficient value in the stock exchange companies

\begin{tabular}{|c|c|c|c|c|c|c|c|c|}
\hline $\begin{array}{l}\text { Correlat } \\
\text { ion }\end{array}$ & $\begin{array}{l}\text { CLUST } \\
\text { ER }\end{array}$ & $\begin{array}{l}\text { ILLI } \\
\mathbf{Q}\end{array}$ & $\begin{array}{l}\text { MKTC } \\
\text { AP }\end{array}$ & $\begin{array}{l}\text { PRI } \\
\text { CE }\end{array}$ & $\begin{array}{l}\text { PVO } \\
\text { LT }\end{array}$ & $\begin{array}{l}\text { RVO } \\
\text { LT }\end{array}$ & $\begin{array}{l}\text { SPEA } \\
\text { RD }\end{array}$ & $\begin{array}{l}\text { TU } \\
\text { RN }\end{array}$ \\
\hline CLUSTER & 1.000 & & & & & & & \\
\hline ILLIQ & -0.212 & $\begin{array}{l}1.00 \\
0\end{array}$ & & & & & & \\
\hline MKTCAP & 0.103 & $\begin{array}{l}0.14 \\
0\end{array}$ & 1.000 & & & & & \\
\hline PRICE & 0.310 & $\begin{array}{r}- \\
0.211\end{array}$ & 0.026 & $\begin{array}{l}1.00 \\
0\end{array}$ & & & & \\
\hline PVOLT & 0.012 & $\begin{array}{l}0.01 \\
0\end{array}$ & 0.010 & $\begin{array}{l}0.14 \\
5\end{array}$ & $\begin{array}{l}1.00 \\
0\end{array}$ & & & \\
\hline RVOLT & 0.098 & $\begin{array}{l}0.21 \\
0\end{array}$ & 0.28 & $\begin{array}{l}0.21 \\
4\end{array}$ & $\begin{array}{l}0.23 \\
9\end{array}$ & $\begin{array}{l}1.00 \\
0\end{array}$ & & \\
\hline SPEARD & 0.071 & $\begin{array}{r}- \\
0.312\end{array}$ & -0.064 & $\begin{array}{l}0.41 \\
7\end{array}$ & $\begin{array}{l}0.07 \\
6\end{array}$ & $\begin{array}{l}0.07 \\
6\end{array}$ & 1.000 & \\
\hline TURN & -0.067 & $\begin{array}{l}0.29 \\
8\end{array}$ & 0.251 & $\begin{array}{r}- \\
0.129\end{array}$ & $\begin{array}{l}0.23 \\
4\end{array}$ & $\begin{array}{l}0.23 \\
5\end{array}$ & -0.254 & $\begin{array}{l}1.00 \\
0\end{array}$ \\
\hline
\end{tabular}

As it is known, the highest value of the correlation coefficient between the variables is 0.554 and other very small amounts obtained this indicates that there is no high linearity between the explanatory variables. 


\subsection{Model Estimates:}

Self-correlation test is one of the classic assumptions of regression. Watson's statistic is a test statistic that is used to examine the existence of autocorrelation (the relationship between values separated by a specific lag) between residuals in regression analysis. The value of this statistic is always between ( 0 to 4$)$ and the thresholds to accept are as follows: The value of 2 for this statistic indicates the lack of self-correlation, which is the optimal condition in the main residual assumptions in regression analysis. Not at all less than 2 consecutive positive correlations (Is a continuous correlation in which the positive residual value for one observation increases the chance of the positive residual for the other observation, and vice versa) and a value greater than 1 indicates a negative continuous correlation between the residuals. It should be noted that if the test statistic is less than 1 or more than 1, the alarm is a positive or negative correlation between the residuals. As it is known, the value of this statistic in this study is close to 2, this value indicates the absence of autocorrelation, which is the case in the main assumptions about residuals.

Table 6- Estimation of research model

\begin{tabular}{|c|c|c|c|c|c|c|c|c|}
\hline & \multicolumn{4}{|c|}{ Stock companies } & \multicolumn{4}{|c|}{ OTC companies } \\
\hline & \multicolumn{2}{|c|}{ volatility=PVOLT } & \multicolumn{2}{|c|}{ volatility=RVOLT } & \multicolumn{2}{|c|}{ volatility=PVOLT } & \multicolumn{2}{|c|}{ volatility=RVOLT } \\
\hline variabl & $\begin{array}{l}\text { Coeffi } \\
\text { cient }\end{array}$ & $\begin{array}{l}\text { Signifi } \\
\text { cant }\end{array}$ & $\begin{array}{l}\text { Coeffi } \\
\text { cient }\end{array}$ & $\begin{array}{l}\text { Signifi } \\
\text { cant }\end{array}$ & $\begin{array}{l}\text { Coeffi } \\
\text { cient }\end{array}$ & $\begin{array}{l}\text { Signifi } \\
\text { cant }\end{array}$ & $\begin{array}{l}\text { Coeffi } \\
\text { cient }\end{array}$ & $\begin{array}{l}\text { Signifi } \\
\text { cant }\end{array}$ \\
\hline $\begin{array}{l}\text { CLUST } \\
\text { ER }\end{array}$ & $\begin{array}{l}0.0230 \\
85\end{array}$ & $\begin{array}{l}0.4184 \\
25\end{array}$ & $\begin{array}{c}- \\
0.000021\end{array}$ & $\begin{array}{l}0.2181 \\
6\end{array}$ & $\begin{array}{c}- \\
0.0572412\end{array}$ & $\begin{array}{l}0.6473 \\
25\end{array}$ & $\begin{array}{l}0.0467 \\
424\end{array}$ & 0.5831 \\
\hline ILLIQ & $\begin{array}{c}- \\
0.5432643\end{array}$ & $\begin{array}{l}0.4455 \\
75\end{array}$ & $\begin{array}{l}1.4418 \\
656\end{array}$ & 0 & $\begin{array}{l}0.0316 \\
194\end{array}$ & $\begin{array}{l}0.0000 \\
75\end{array}$ & $\begin{array}{l}0.3859 \\
214\end{array}$ & $\begin{array}{c}0.0001 \\
4\end{array}$ \\
\hline $\begin{array}{l}\text { LNMK } \\
\text { TCAP }\end{array}$ & $\begin{array}{c}- \\
0.92249\end{array}$ & 0 & $\begin{array}{l}0.3704 \\
512\end{array}$ & $\begin{array}{l}0.6880 \\
5\end{array}$ & $\begin{array}{l}3.11 \mathrm{E}- \\
01\end{array}$ & $\begin{array}{l}0.0047 \\
25\end{array}$ & $\begin{array}{l}2.04 \mathrm{E}- \\
01\end{array}$ & $\begin{array}{l}0.0051 \\
8\end{array}$ \\
\hline $\begin{array}{l}\text { LNPRI } \\
\text { CE }\end{array}$ & $\begin{array}{l}0.8543 \\
912\end{array}$ & $\begin{array}{l}0.0646 \\
5\end{array}$ & $\begin{array}{l}0.0218 \\
666\end{array}$ & 0 & $\begin{array}{l}0.2986 \\
654\end{array}$ & 0.0012 & $\begin{array}{l}0.1301 \\
094\end{array}$ & $\begin{array}{c}0.0033 \\
6\end{array}$ \\
\hline $\begin{array}{l}\text { MARK } \\
\text { ET }\end{array}$ & $\begin{array}{c}- \\
0.568781\end{array}$ & 0.0951 & $\begin{array}{c}- \\
0.0037366\end{array}$ & 0 & $\begin{array}{l}0.1336 \\
29\end{array}$ & $\begin{array}{l}0.2356 \\
5\end{array}$ & $\begin{array}{l}0.0904 \\
562\end{array}$ & $\begin{array}{l}0.2151 \\
1\end{array}$ \\
\hline $\begin{array}{l}\text { SPEAR } \\
\text { D }\end{array}$ & $\begin{array}{c}- \\
0.0368523\end{array}$ & $\begin{array}{l}0.5465 \\
25\end{array}$ & $\begin{array}{l}0.0002 \\
38\end{array}$ & 0 & $\begin{array}{l}0.3554 \\
873\end{array}$ & $\begin{array}{l}0.2254 \\
5\end{array}$ & $\begin{array}{l}0.2399 \\
115\end{array}$ & $\begin{array}{l}0.2067 \\
8\end{array}$ \\
\hline
\end{tabular}




\begin{tabular}{|c|c|c|c|c|c|c|c|c|}
\hline TURN & $\begin{array}{l}0.0868 \\
995\end{array}$ & $\begin{array}{l}0.0514 \\
5\end{array}$ & $\begin{array}{l}-2.38 \mathrm{E}- \\
05\end{array}$ & $\begin{array}{c}0.2226 \\
6\end{array}$ & $\begin{array}{c}- \\
0.3996476\end{array}$ & $\begin{array}{l}0.0431 \\
25\end{array}$ & $\begin{array}{c}- \\
0.2584821\end{array}$ & $\begin{array}{l}0.0459 \\
2\end{array}$ \\
\hline C & $\begin{array}{c}- \\
9.5666994\end{array}$ & $\begin{array}{l}0.1755 \\
75\end{array}$ & $\begin{array}{c}- \\
0.0156618\end{array}$ & $\begin{array}{l}0.0000 \\
9\end{array}$ & $\begin{array}{c}- \\
31.169207\end{array}$ & 0 & $\begin{array}{c}- \\
19.239177\end{array}$ & 0 \\
\hline \multirow{4}{*}{ 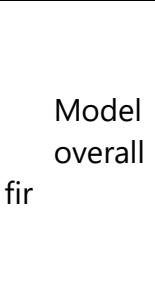 } & \multicolumn{2}{|c|}{$F=13.64078$} & \multicolumn{2}{|c|}{$F=22.4095$} & \multicolumn{2}{|c|}{$F=12.2309$} & \multicolumn{2}{|c|}{$F=15.32045$} \\
\hline & \multicolumn{2}{|c|}{$\operatorname{prob}(\mathrm{F})=0.000$} & \multicolumn{2}{|c|}{$\operatorname{prob}(F)=0.000$} & \multicolumn{2}{|c|}{$\operatorname{prob}(\mathrm{F})=0.000$} & \multicolumn{2}{|c|}{$\operatorname{prob}(\mathrm{F})=0.000$} \\
\hline & \multicolumn{2}{|c|}{ D.W $=2.0857$} & \multicolumn{2}{|c|}{ D.W $=1.87432$} & \multicolumn{2}{|c|}{ D.W $=1.90905$} & \multicolumn{2}{|c|}{ D.W $=2.046063$} \\
\hline & $\begin{array}{l}R^{\prime}= \\
0.28164\end{array}$ & & $\begin{array}{l}R^{\prime}= \\
0.72368\end{array}$ & & $\begin{array}{l}R^{\prime}= \\
0.49702\end{array}$ & & $\mathrm{R}^{\prime}=$ & \\
\hline
\end{tabular}

The results of estimating the model regression model are reported in Table (6). The results of model estimation and significance level for Fs are all less than 0.05 . It indicates that the input variables, including control and independent variables, are significant at $95 \%$ confidence level and indicate appropriate fit of the model.

- Investigation of the effect of CLUSTER price clusters on stock price volatility shows that: The coefficient value for volatility $=$ PVOLT is equal to $(0.023085)$ and is significant $(0.418425)$ which is not greater than the $5 \%$ error level and is not significant.

- Investigation of the effect of CLUSTER price clusters on stock price volatility shows that the coefficient value for volatility $=$ RVOLT is equal $(-0.000021)$ and is significant $(0.2424)$ which is not greater than $5 \%$ error level.

- Investigation of the effect of CLUSTER price clusters on stock price volatility shows that: The coefficient value for volatility $=$ PVOLT $(-0.0572412)$ is obtained and the value is significant $(0.6473)$ which is not greater than $5 \%$ error level.

- Investigation of the effect of CLUSTER price clusters on stock price volatility shows that the coefficient value for volatility $=$ PVOLT $(-0.0572412)$ is obtained and the value is significant $(0.6473)$ which is not greater than $5 \%$ error level.

- Investigation of the effect of CLUSTER price clusters on stock price volatility shows that the coefficient value for volatility $=$ RVOLT is equal $(0.0467)$ and is significant $(0.5831)$ which is not greater than $5 \%$ error level. 


\section{Conclusion}

There is a great deal of evidence today that financial asset price volatility is spreading to other assets and markets. The extent of the turbulence is increasing with the expansion of telecommunication systems and interdependence of financial markets. It is important to identify the mechanisms of return volatility and price volatility fluctuations between different financial assets for various reasons. The volatility of asset fluctuations gives us information about market performance. In an efficient market, returns on one asset should not be predictable using previous returns on other assets. The turbulence between return on assets also makes it possible to use a profitable trading strategy. If the benefit of this strategy is higher than its trading cost, it is potentially a cause for market efficiency. Identifying the turbulence mechanisms in financial markets also plays an important role in portfolio selection and risk reduction or in other words portfolio management. In this paper, we tried to study stock price volatility in proportion to stock price clusters. The research findings showed that: There is no significant relationship between stock price volatility and price clusters in the OTC market and the stock market. Investing in stock price changes in the stock market is always an important issue. The importance of this issue stems from its use to predict stock prices in the stock market. Investigating and analyzing the volatility across markets for decades has been the subject of much practical emphasis by theorists and researchers in various fields. The complex environment of the financial and economic markets and the close relationship of these markets with each other, as well as the critical need to anticipate future financial and economic scenarios, Researchers have encouraged the financial sector to discover and analyze these inter-market relationships so that they can take an effective and forward-looking step toward achieving the goals of the financial and economic system. Given the applicability of the present research topic and the vast research space, the following researchers are suggested:

1- It is suggested that the impact of different classes of firms on the capital market from the parallel markets of the capital market be examined separately; The model extracted 
from this study will be effective in predicting the volatility of returns in the relevant industry.

2- It is suggested that; Test the effect of volatility of financial intermediation index volatility on industry index volatility; by performing this test, the extent and nature of this contagion is determined and the estimation model of this study predicts the fluctuations of firms in the financial intermediation index because companies in the financial intermediation industry have devoted a percentage of their portfolio to investing in manufacturing companies in the industry index and are impacted by a lag in their returns.

3- It is recommended that the present study be evaluated to compare the results with other existing models, to ensure the effectiveness of each of these models for users to achieve. Always stepping on the path to the goal is accompanied by constraints that make it slow. Research as a process towards achieving the goal of problem solving is no exception. In this regard, the limitations of the present study are as follows:

One of the most important limitations of the research is the existence of inflation, which makes the information in the financial statements unable to accurately represent the financial position and results of corporate operations.

- The hypotheses of this study were examined in general while we could examine and compare them separately for certain industries.

- Using different accounting methods by different companies makes the difference in the financial statements of companies not only influenced by their financial and operating decisions; As a result, financial information does not properly reflect the financial and operating status of companies.

- Due to the sampling method used in this study, many of the member companies of the statistical community were excluded from the sample because of lack of some of the desired characteristics. Therefore, caution should be exercised when generalizing the results of the research to all listed companies in the Tehran Stock Exchange. 


\section{References}

Adaraki, Mohammad Reza and Reza Tehrani. Modeling and predicting the fluctuations of the total index price in Tehran Stock Exchange using the conditional arbitrary variance patterns. Regression, First International Conference on Econometrics, Methods and Applications, Sanandaj, Islamic Azad University, Sanandaj Branch, 2002.

Benjamin M. Blau, Todd G. Griffith. Price clustering and the stability of stock prices, Journal of Business Research, Volume 69, Issue 10, October 2016, Pages 3933-3942, 2016.

Binoy B. Nair, P. K. Saravana Kumar, N. R. Sakthivel, U. Vipin. Clustering stock price time series data to generate stock trading recommendations: An empirical study, Expert Systems with Applications, Volume 70, 15 March 2017, Pages 20-36, 2017.

Edirisinghe, NCP \& X Zhang, Portfolio selection under DEA-based relative financial strength indicators: case of US industries, Journal of the Operational Research Society, 57, 2002.

Gang-Jin. W. X. Chi. Cross-correlations between WTI crude oil market and US stock market: A perspective from econophysics, Acta Phys. Pol. B 43, 2012.

Gholamreza, Keshavarzahdad; Ebrahimi، Seyyedbabak, Jafarabadi، Akbar. Investigating the turbulence between stock returns of cement industry and its related industries in Iran. Iranian Economic Research: Summer, Volume 16, Issue 47; 129-162, 2001.

Kumar Paresh Narayan, Russell Smyth. Has political instability contributed to price clustering on Fiji's stock market?, Journal of Asian Economics, Volume 28, October 2013, Pages 125130, 2013.

Leventis. Angelos Gkanoutas, Nesvetailova. Anastasia. Financialisation, oil and the Great Recession, Energy Policy,Volume 86, November 2015, Pages 891-902, 2015.

Lo A. W. and A. C. MacKinlay. "Stock Market Prices Do not Follow Random Walk: Evidence from a Simple Specification Test: Review of Financial Studies", The Review of Financial Studies, vol. 1, no. 1, pp. 41-66, 1988.

Sean S. Jung, Woojin Chang. Clustering stocks using partial correlation coefficients, Physica A: Statistical Mechanics and its Applications, Volume 462, 15 November 2016, Pages 410420, 2016.

Tripathi, Vanita., Kumar, Arnav. Relationship between Inflation and Stock Returns - Evidence from BRICS markets using Panel Co integration Test, International Journal of Accounting and Financial Reporting ISSN 2162-3082 2014, Vol. 4, No. 2, 2014.

Y. J. Zhang, J. Wang. Exploring the WTI crude oil price bubble process using the Markov regime switching model, Physica A 421 (2015) 377-387, 2015. 